GRADIATION\&APPLICATIONS

ISSN 2466-4294 (online) | rad-journal.org

Vol. 3 | Issue 2 | pp. 138-142, 2018

doi: 10.21175/RadJ.2018.02.023

Original research paper

\title{
CHEMICALLY DEPOSITED ELECTROCHROMIC FILMS AND SOLAR LIGHT MODULATION ${ }^{*}$
}

\author{
Isak Aliji ${ }^{1,2}$, Julijana Velevska ${ }^{2^{* *}}$, Metodija Najdoski3, Atanas Tanuševski² \\ ${ }^{1}$ Faculty of Natural Sciences and Mathematics, Tetovo State University, Tetovo, Macedonia \\ ${ }^{2}$ Institute of Physics, Faculty of Natural Sciences and Mathematics, Sts Cyril ad Methodius University, Skopje, \\ Macedonia \\ 3 Institute of Chemistry, Faculty of Natural Sciences and Mathematics, Sts Cyril and Methodius University, Skopje, \\ Macedonia
}

\begin{abstract}
The chemical bath deposition method was employed for the preparation of iron hexacyanoferrate ( $\mathrm{FeHCF}$ ), cobalt hexacyanoferrate (CoHCF), and tungsten oxide $\left(\mathrm{WO}_{3}\right)$ films. The films were deposited onto fluorinedoped tin oxide (FTO) coated glass substrates. For practical electrochromic investigations, an electrochromic test device (ECTD) was constructed consisting of FeHCF (or CoHCF) films as the working electrode, together with $\mathrm{WO}_{3}$ film as the counter electrode, in $1 \mathrm{M} \mathrm{KCl}$ aqueous solution as an electrolyte. Visible transmittance spectra were recorded in-situ. The output integral of the spectral intensity and the spectral modulation, as well as saved energy, were calculated by taking the solar irradiance spectrum AM 1.5 for a normal illumination on the ECTD and its transmittance data in the bleached and colored states.
\end{abstract}

Key words: Chemical deposition, cobalt hexacyanoferrate, electrochromism, iron hexacyanoferrate, solar light modulation, tungsten oxide

\section{INTRODUCTION}

Last century was the century of industrial and technological development which caused an increase in emissions and heat. The final result was increased air pollution and temperature of the Earth's climate. The problem of air pollution is not only a "privilege" of developed countries but also of the developing and undeveloped countries. This problem is especially present in the winter, when we have increased energy consumption. Buildings, using energy for lighting, heating and cooling, have more impact on the environment than industry and transportation because they consume more than one third of the overall energy world-wide. There is no doubt that one of the biggest problems of the present century is air pollution, and one of the biggest challenges throughout the world is environmental protection. The challenge is too complex and requires multiple simultaneous responses and solutions. It is obvious that reducing energy consumption in buildings must be a part of the solution.

Over the last decade, building design has been oriented toward the reduction of energy consumption and the protection of the environment. On the other hand, people's comfort requires a big percentage of glass areas in buildings because of the positive impact that natural daylight has on people's health and wellbeing [1]. Beside these desirable benefits, highly glazed buildings also have negative effects in terms of indoor comfort: buildings are difficult to heat during the winter and tend to overheat in the summer. It means that achieving good comfort inside highly glazed buildings is mostly at the cost of high-energy consumption [2]. As one of the less energy efficient components of the building envelope, glazing has a huge impact on the building energy consumption. This is the reason why window choice plays a crucial role in the reduction of building energy consumption. The control of the incident solar radiation through the windows is very important for achieving indoor comfort and greater energy efficiency in buildings [3].

The need to achieve both, visual comfort and energy efficiency inside the buildings, led to the development of innovative dynamic glazing technologies, whose aim is to reduce heat loss, and to control incoming solar radiation, in order to maximize the solar gain in winter and minimize it in summer, as well as to ensure the best natural lighting conditions with no glare [4]. Among these technologies, electrochromic glazing (smart windows) offers the highest potential for adaptation in regard to solar radiation [1], [5]. The development of smart windows is the subject of intensive research, as the implementation of such technology would lead to a

\footnotetext{
* This paper was presented at the Sixth International Conference on Radiation and Applications in Various Fields of Research (RAD 2018), Ohrid, Macedonia, 2018.

julev@pmf.ukim.mk
} 
significant reduction in energy consumption in highly glazed buildings by reducing cooling loads, heating loads and the demand for electric lighting, as well as improving indoor comfort due to less glare and thermal discomfort [6], [7].

Smart windows can be reversibly switched between transparent and colored states by means of a small applied voltage resulting in thermal and optical properties which can be dynamically controlled [8]. This dynamic control is due to special materials that have electrochromic properties.

A standard electrochromic device consists of an ionic conductor (electrolyte) placed between the electrochromic film and counter electrode, which in turn is placed between transparent conductors [6], [8]. The counter electrode may also have electrochromic properties complementary to those of the first electrochromic film. When a small potential is applied between the transparent conductors, ions are inserted or extracted from the electrochromic film due to an electrochemical reaction, resulting in a modulation of optical properties [9].

The electrochromic film is the optically active element in the electrochromic device. It is deposited on the transparent conductor. The deposition method has a crucial role in the electrochromic properties of the films, which means that different methods create films with different electrochromic properties.

In this paper, we prepared $\mathrm{WO}_{3}, \mathrm{FeHCF}$, and CoHCF thin films via a chemical bath method. The solar light modulation was investigated using an electrochromic test device (ECTD) consisting of a FeHCF (or CoHCF) film as the working electrode, and $\mathrm{WO}_{3}$ film as the counter electrode in $1 \mathrm{M} \mathrm{KCl}$ aqueous solution as an electrolyte.

\section{MATERIALS AND METHODS}

\subsection{Deposition of the films}

Tungsten oxide $\left(\mathrm{WO}_{3}\right)$, iron hexacyanoferrate (FeHCF), and cobalt hexacyanoferrate (CoHCF) films were chemically deposited onto fluorine-doped tin oxide (FTO) coated glass substrates commercially available, with a sheet resistance of about 10-20 $\Omega / \square$ and a transparency of about $80 \%$.

The deposition of $\mathrm{WO}_{3}$ films was carried out from an aqueous solution of $\mathrm{Na}_{2} \mathrm{WO}_{4} \cdot 2 \mathrm{H}_{2} \mathrm{O}$, while the deposition of the hexacyanoferrates was performed from two solutions. For the deposition of FeHCF the first solution was a mixture of $0.1 \mathrm{~mol} / \mathrm{dm}^{3} \mathrm{Fe}_{2}\left(\mathrm{SO}_{4}\right)_{3}$, aqueous solution of $\mathrm{H}_{2} \mathrm{O}$, EDTA, and $3 \mathrm{~mol} / \mathrm{dm}^{3} \mathrm{HCl}$, while the second solution was a mixture of $0.1 \mathrm{~mol} / \mathrm{dm}^{3}$ $\mathrm{K}_{4}\left[\mathrm{Fe}(\mathrm{CN})_{6}\right], \mathrm{H}_{2} \mathrm{O}$ and $3 \mathrm{~mol} / \mathrm{dm}^{3} \mathrm{HCl}$. The deposition of CoHCF films was carried out from a mixed 0.1 $\mathrm{mol} / \mathrm{dm}^{3}$ aqueous solution of $\mathrm{CoCl}_{2}, \mathrm{H}_{2} \mathrm{O}$ and 3 $\mathrm{mol} / \mathrm{dm}^{3} \mathrm{HCl}$ as the first solution, and an aqueous solution prepared by mixing $0.1 \mathrm{~mol} / \mathrm{dm}^{3} \mathrm{~K}_{4}\left[\mathrm{Fe}(\mathrm{CN})_{6}\right]$, $\mathrm{H}_{2} \mathrm{O}$, and $3 \mathrm{~mol} / \mathrm{dm}^{3} \mathrm{HCl}$ as the second solution. The thickness of the $\mathrm{WO}_{3}$ films depends on the deposition time, while the thickness of the hexacyanoferrate films depends on the number of immersion cycles. In this paper, the investigation was carried out with $150-\mathrm{nm}$ - thick $\mathrm{WO}_{3}$ films, $140-\mathrm{nm}$ FeHCF films and $370-\mathrm{nm}$ CoHCF films. The detailed descriptions of the deposition procedures were previously published elsewhere [10 - 12]

\subsection{Characterization}

In order to investigate the solar light modulation, an electrochromic test device (ECTD) was designed. It consisted of a home-built glass cell filled with the $1 \mathrm{M}$ $\mathrm{KCl}$ aqueous solution as an electrolyte in which two electrodes (working and counter) were immersed [3].

The visible transmission spectra of the ECTD were investigated using Varian CARY 50 Scan UV-Visible spectrophotometer in the wavelength range from 350 to $900 \mathrm{~nm}$.

Two experiments were carried out. In the first experiment (A), FeHCF thin film deposited on an FTO substrate was used as a working electrode in the ECTD, while $\mathrm{CoHCF}$ thin film deposited on an FTO substrate was used as a working electrode in the second one (B). $\mathrm{A} \mathrm{WO}_{3}$ thin film deposited on an FTO substrate was used as a counter electrode in both measurements. An electrochromic cell with two clean FTO substrates filled with electrolyte was measured as 100\% background. The spectra were recorded in both the bleached and colored state of the films. A potential of $\pm 2 \mathrm{~V}$ was used for the coloration and bleaching of the ECTD. The active surface area of the electrodes was approximately $6 \mathrm{~cm}^{2}$.

Using the solar irradiance spectrum AM 1.5 [13] for a normal incident illumination on the ECTD together with the recorded transmittance spectra of the ECTD in the bleached and colored states, the output integral of the spectral intensity, the integral of the spectral modulation, and the saved energy were calculated [14], [15].

\section{RESULTS AND DISCUSSION}

All the films investigated in this work revealed good electrochromic properties [3], [16-18]. They reversibly changed color by alternative application of a positive and negative potential.

$\mathrm{WO}_{3}$ is a cathodically coloring material, which means that it possesses a reduced colored state, i.e., coloration at a negative potential. Chemically deposited $\mathrm{WO}_{3}$ thin films were transparent in the as-deposited state and changed their color between transparent (positive potential) and deep blue (negative potential) [16].

Unlike $\mathrm{WO}_{3}, \mathrm{FeHCF}$ and $\mathrm{CoHCF}$ are anodically coloring materials, which means that they possess an oxidized colored state, i.e., coloration at a positive potential. Chemically deposited CoHCF films were also transparent in the as-deposited state and changed their color between brown (positive potential) and transparent (negative potential) [12].

FeHCF is a polyelectrochromic material, which means that it displays more than two distinct visible color changes (more than two red-ox states are available). In a thin film form, it has a deep blue color in its as-deposited state, green (partly oxidized state) 
and yellow (fully oxidized state) color at a positive potential and is transparent at a negative potential [17].

The optical transmittance spectra of the ECTD in the wavelength range from $350 \mathrm{~nm}$ to $900 \mathrm{~nm}$ in transparent (bleached) and colored (darkened) states for both experiments, are presented in Fig. 1. One can see a significant transmittance difference that occurs in both systems.

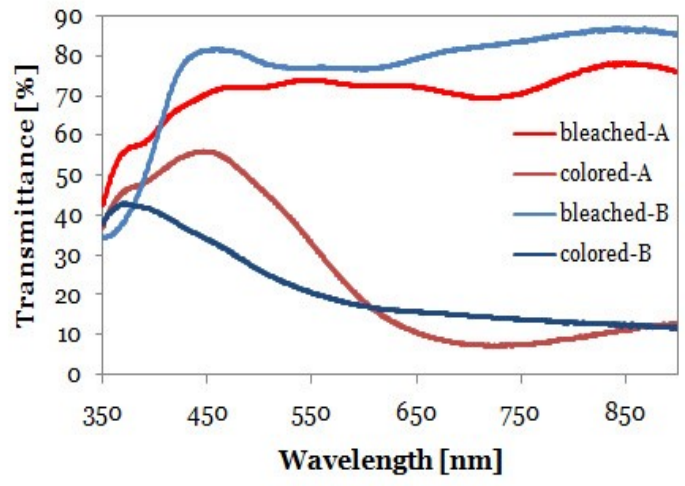

Figure 1. Visible transmittance spectra of ECTD in the bleached and colored states after application of $\mathrm{U}= \pm 2 \mathrm{~V}$.

A denotes the FeHCF-WO3 system and B denotes the $\mathrm{CoHCF}-\mathrm{WO}_{3}$ system

The contrast ratio was calculated from the visible transmittance spectra using the equation [3], [19]:

$$
C R=\frac{T_{b}(\lambda)}{T_{c}(\lambda)}
$$

where $T_{b}(\lambda)$ and $T_{c}(\lambda)$ are the transmittance data (at a particular wavelength) of the ECTD in its bleached and colored states respectively.

Figure 2 presents the contrast ratio of the FeHCF- $\mathrm{WO}_{3}-$ (A) and CoHCF- $\mathrm{WO}_{3}$-based (B) ECTD, between the transparent and the colored states, in the wavelength range between 350 and $900 \mathrm{~nm}$, calculated by Equation (1).

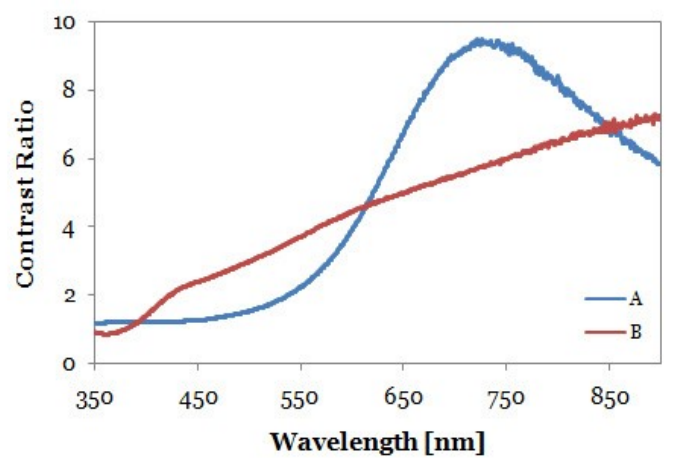

Figure 2. Contrast Ratio of the FeHCF-WO3- (A), and CoHCF- $-\mathrm{WO}_{3}$-based (B) ECTD, between its transparent and colored states.

As can be seen from Fig. 2, the FeHCF-WO3 based ECTD (A) achieves a maximum contrast ratio of 9.5 at
$720 \mathrm{~nm}$, while the contrast ratio of the $\mathrm{CoHCF}-\mathrm{WO}_{3}$ based ECTD (B) increases with increasing wavelength along the whole visible spectrum, with a tendency to continue increasing in the infrared region.

Finally, taking the solar irradiance spectrum AM 1.5 as a normal incident illumination on a $\mathrm{FeHCF}-\mathrm{WO}_{3}-$ and $\mathrm{CoHCF}-\mathrm{WO}_{3}$-based ECTD and its transmittance spectra in the bleached and colored state for both systems, the integrals of the spectral modulation (M ) and saved energy $(S E)$ were calculated by using the equation [15]:

$$
\mathrm{M}=\frac{\int_{\lambda_{1}}^{\lambda_{2}}\left(T_{b}(\lambda)-T_{c}(\lambda)\right) \cdot I(\lambda) d \lambda}{\int_{\lambda_{1}}^{\lambda_{2}} T_{b}(\lambda) \cdot I(\lambda) d \lambda}
$$

where $T_{b}(\lambda)$ and $T_{c}(\lambda)$ are the transmittance at the bleached and colored state respectively, $I(\lambda)$ is the solar irradiation intensity at a specific wavelength, expressed in (W $\left.\mathrm{m}^{-2} \mathrm{~nm}^{-1}\right)$. The solar energy is calculated by integrating the solar intensity in the wavelength range between 350 and $900 \mathrm{~nm}$. The saved energy is calculated as:

$$
S E=\int_{\lambda_{1}}^{\lambda_{2}}\left(T_{b}(\lambda)-T_{c}(\lambda)\right) \cdot I(\lambda) d \lambda
$$

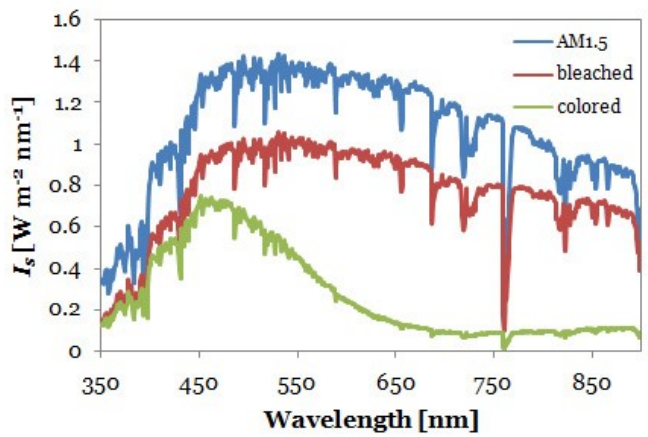

Figure 3. Spectral intensities of the transmitted AM 1.5 solar irradiance spectrum across the $\mathrm{FeHCF}-\mathrm{WO}_{3}$-based ECTD in the bleached and colored states.

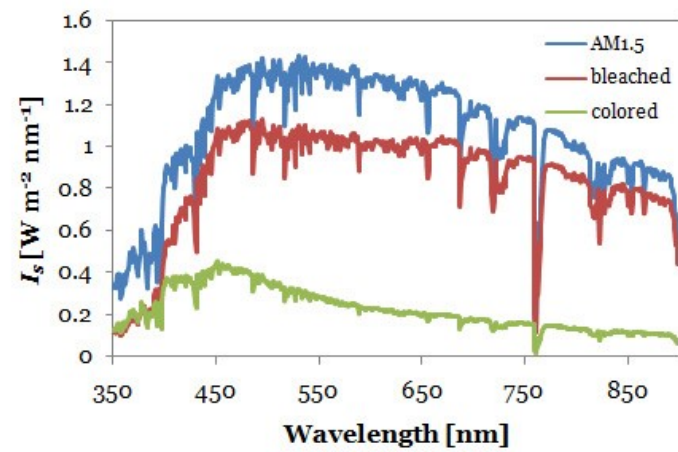

Figure 4. Spectral intensities of the transmitted AM 1.5 solar irradiance spectrum across the CoHCF-WO $\mathrm{WO}_{3}$ based ECTD in the bleached and colored states. 
The calculated output spectral intensities transmitted across the FeHCF- $\mathrm{WO}_{3}$ and $\mathrm{CoHCF}-\mathrm{WO}_{3}$ based ECTD are presented in Fig. 3 and Fig. 4 respectively.

The results from the numerical integration for the spectral intensity within the visible region (from 350 to $900 \mathrm{~nm}$ ), saved energy, and solar energy modulation, are presented in Table 1.

Table 1. Integral transmitted intensity $\left(I_{t}\right)$ from $350-900 \mathrm{~nm}$ across the $\mathrm{FeHCF}-\mathrm{WO}_{3}$ and $\mathrm{CoHCF}-\mathrm{WO}_{3}$ systems in the bleached and colored states, together with the saved energy $(S E)$ and solar energy modulation $(M)$

\begin{tabular}{|l|c|c|c|c|}
\hline System & State & $I_{t}\left[\mathrm{~W} \cdot \mathrm{m}^{-2}\right]$ & $S E\left[\mathrm{~W} \cdot \mathrm{m}^{-2}\right]$ & $M[\%]$ \\
\hline FeHCF-WO & bleached & 422.95 & 274.73 & 65 \\
& colored & 148.22 & & \\
$\mathrm{CoHCF}^{2}-\mathrm{WO}_{3}$ & bleached & 464.66 & 343.24 & 74 \\
& colored & 121.42 & & \\
\hline
\end{tabular}

As can be seen from Table 1 , the estimated saved energy and integrated intensity modulation are 274.73 $\mathrm{W} \mathrm{m}{ }^{-2}$ and $65 \%$ for the $\mathrm{FeHCF}-\mathrm{WO}_{3}$-based device, and $343.24 \mathrm{~W} \mathrm{~m}^{-2}$ and $74 \%$ for the CoHCF- $\mathrm{WO}_{3}$-based device. These considerable values give the opportunity for chemically deposited FeHCF, CoHCF, and $\mathrm{WO}_{3}$ electrochromic films to be implemented in smart window technologies.

\section{CONCLUSION}

Thin films of iron hexacyanoferrate, cobalt hexacyanoferrate, and tungsten oxide were prepared by the chemical bath deposition method. All the films revealed electrochromism, reversibly changing color from transparent to dark by applying a small potential and back to transparent, when the potential was reversed.

Two electrochromic test devices were constructed: a FeHCF- $\mathrm{WO}_{3}$-based, and a $\mathrm{CoHCF}-\mathrm{WO}_{3}$-based. The maximum light intensity ability, and saved energy, as the AM 1.5 spectrum is taken as an input were calculated to be $65 \%$ and $274.73 \mathrm{~W} \mathrm{~m}^{-2}$ for the FeHCF$\mathrm{WO}_{3}$ based ECTD, and $74 \%$ and $343.24 \mathrm{~W} \mathrm{~m}^{-2}$ for the Co $\mathrm{HCF}-\mathrm{WO}_{3}$ based ECTD. These values make these films suitable for implementation in electrochromic devices for solar light modulation.

\section{REFERENCES}

1. J. M. Dussault, L. Gosselin, T. Galtsian Amundson, "Assesment of buildings energy efficiency with smart window glazing curtain walls," in Proc. Smart materials, structures \& NDT in aerospace conference (NDT Canada 2011), Montreal, Canada, 2011, pp $1-10$. Retrieved from: http://www.ndt.net/article/ndtcanada 2011/papers/12 Dussault Rev2.pdf; Retrieved on: Aug. 27, 2018

2. A. S. Bahaj, P. A. B. James, M. F. Jentsch, "Potential of emerging glazing technologies for highly glazed buildings in hot arid climates," Energ. Buildings, vol. 40, no. 5, pp. $720-731,2008$. DOI: 10.1016/j.enbuild.2007.05.006

3. J. Velevska, N. Stojanov, M. Pecovska - Gjorgjevich, M. Najdoski., "Visible light modulation using chemically deposited electrochromic thin films," Radiation \& Applications., vol. 2, no. 1, pp. $35-40$, Apr. 2017. DOI: 10.21175/RadJ.2017.01.008

4. M. Casini, "Smart windows for energy efficiency of buildings," in Proc. of $2^{\text {nd }}$ International Conference on Advances in Civil, Structural and Environmental Engineering (ACSEE 2014), Zurich, Switzerland, 2014, pp $273-281$.

Retrieved from: https://www.seekdl.org/assets/pdf/20 141111 063159.pdf;

Retrieved on: Aug. 27, 2018

5. W. S. E. Bahlol, "Smart glazing systems for low energy architecture," in Proc. SB1O: Sustainable Architecture and Urban Development (SAUD '10), Amman, Jordan, 2010, pp. $149-165$.

Retrieved from: https://www.irbnet.de/daten/iconda/C IB22604.pdf; Retrieved on: Aug. 27, 2018

6. R. Baetens, B. P. Jelle, A. Gustavsen, "Properties, requirements and possibilities of smart windows for dynamic daylight and solar energy control in buildings: a state-of-the-art review," Sol. Energy Mater. Sol. Cells vol. 94, no. 2, pp 87-105, Feb. 2010

DOI: $10.1016 /$ j.solmat.2009.08.021

7. M. Z. Sialvi et al., "Electrochromic and Colorimetric Properties of Nickel(II) Oxide Thin Films Prepared by Aerosol-Assisted Chemical Vapor Deposition," ACS Appl. Mater. Interfaces, vol. 5 no. 12, pp. 5675 - 5682, Jun. 2013.

DOI: $10.1021 / \mathrm{am} 401025 \mathrm{v}$

PMid: 23748903

8. E. S. Lee, D. L. DiBartolomeo, S. E. Selkowitz, "Electrochromic windows for commercial buildings: monitored results from a full-scale testbed," in Proc. Summer Study on Energy Efficiency in Buildings, Efficiency and Sustainability (ACEEE 200o), Washington (DC), USA, 2000.

Retrieved from: https://aceee.org/files/proceedings/20 oo/data/papers/SSoo_Panel3 3 Paper20.pdf; Retrieved on: Aug. 27, 2018

9. C. G. Granqvist, "Progress in electrochromics: tungsten oxide revisited," Electrochim. Acta, vol. 44 no. 18, pp. 3005 - 3015, May 1999. DOI: 10.1016/Soo13-4686(99)ooo16-X

10. M. Najdoski, T. Todorovski, "A simple method for chemical bath deposition of electrochromic tungsten oxide films," Mater. Chem. Phys., vol. 104, no. 2-3, pp. $483-487$, Aug. 2007. DOI: 10.1016/j.matchemphys.2007.04.035

11. S. Demiri, M. Najdoski, J. Velevska, "A simple chemical method for deposition of electrochromic prussian blue thin films," Mater. Res. Bull., vol. 46, no. 12, pp. $2484-2488$, Dec. 2011

DOI: 10.1016/j.materresbull.2011.08.021

12. И. Алији, "Електрохромизам кај тенки филмови од кобалт хексацијаноферат," презентирана на $2^{p a}$ Конферениија на Докторската школа при Универзитетот “Св. Кирил и Методи", Скопје, Македонија, 2018. (I. Aliji, "Electrochromism in cobalt hexacyanoferrate thin films," presented at the $2^{\text {nd }}$ Doctorial school Conference of the "Sts Cyril and Methodius" University, Skopje, Macedonia, 2018.

13. Standard Tables for Reference Solar Irradiances: Direct Normal and Hemispherical on $37^{\circ}$ Tilted Surface, ASTM G173-03, Jan. 11, 2012. Retrieved from: https://www.astm.org/Standards/G173 htm; Retrieved on: Aug. 27, 2018

14. M. Ristova, R. Neskovska, V. Mirčevski, "Chemically deposited electrochromic cuprous oxide films for solar light modulation," Sol. Energy Mat \& Sol. Cells, vol. 91, no. 14, pp 1361 - 11365, Sep. 2007. 
I. Aliji et al., Chemically deposited electrochromic films..., Rad. Applic., 2018, 3, 2, 138-142

DOI: 10.1016/j.solmat.2007.05.018

15. H.Y. Liao, T.C. Liao, W. H. Chen, C. H. Chang, L. C. Chen, "Molybdate hexacyanoferrate (MoOHCF) thin film: Abrownishred Prussian blue analog for electrochromic window application," Sol. Energy Mat \& Sol. Cells, vol. 145, no. 1, pp 8 - 15, Feb. 2016. DOI: 10.1016/j.solmat.2015.06.062

16. J. Velevska, N. Stojanov, M. Pecovska - Gjorgjevich, M. Najdoski, "Electrochromism in rungsten oxide thin films prepared by chemical bath deposition," J. Electrochem. Sci. Eng., vol. 7, no 1, pp, 27 - 37, 2017. DOI: $10.5599 /$ jese. 357

17. J. Velevska, M. Pecovska - Gjorgjevich, N. Stojanov, M. Najdoski, "Electrochromc properties of Prussian blue thin films prepared by chemical deposition method," Int. J. Sci. Basic. Appl. Res., vol. 25, no. 3, pp. $380-392,2016$.
Retrieved from: http://gssrr.org/index.php?journal=Jo urnalOfBasicAndApplied\&page $=$ article\&op $=$ view\&path ${ }_{5} \mathrm{~B} \%{ }_{5} \mathrm{D}=533.5$ \&path ${ }_{5} \mathrm{~B}{ }_{5} \mathrm{D}=2768$;

Retrieved on: Aug. 27, 2018

18. I. Aliji, M. Najdoski, J. Velevska, "A simple chemical method for deposition of electrochromic cobal hexacyanoferrate thin films," Int. J. Sci. Basic. Appl. Res., vol. 40, no. 1, pp. $242-257,2018$.

Retrieved from: http://gssrr.org/index.php?journal=Jo urnalOfBasicAndApplied\&page $=$ article\&op $=$ view\&path \%5B\%5D=9084\&path\%5B\%5D=4082;

Retrieved on: Aug. 27, 2018

19. S. A. Sapp, G. A. Sotzing, J. R. Reynolds, "High contrast ratio and fast switching dual polymer electrochromic devices," Chem. Mater., vol. 10, no. 8, pp. $2101-2108$, Jul. 1998.

DOI: $10.1021 / \mathrm{cm} 9801237$ 